\title{
Late Cenozoic history of deep water circulation in the western North Pacific: Evidence from Nd isotopes of ferromanganese crusts
}

\author{
HU Rong, CHEN TianYu \& LING HongFei* \\ State Key Laboratory for Mineral Deposits Research, School of Earth Sciences and Engineering, Nanjing University, Nanjing 210093, China
}

Received March 31, 2012; accepted May 3, 2012; published online July 10, 2012

\begin{abstract}
Despite its importance in regulating the global climate, the past deep ocean circulation in the western North Pacific has still been poorly understood. $\mathrm{Nd}$ isotopes of ferromanganese crusts have been proven to be a good proxy to monitor paleoceanic circulation changes. In this study, late Cenozoic Nd isotopic records are recovered from two ferromanganese crusts located near Mariana arc but at different water depths (MKD13: $1530 \mathrm{~m}$, MDD53: $2700 \mathrm{~m}$ ), and their implications for paleocirculation change in this area are explored. From the early to late Miocene, Nd isotopic compositions of MDD53 remained stable, and they were also characterized by the least radiogenic signatures $\left(\varepsilon_{\mathrm{Nd}}-4.0\right.$ to -5.0$)$ compared to crusts of similar water depths in the Miocene North Pacific. Afterward, an abrupt increase in its $\varepsilon_{\mathrm{Nd}}$ value occurred in the Pliocene. In contrast, Nd isotopes of MKD13 became more radiogenic with time in the Miocene and were almost invariable thereafter. The continual increase in $\varepsilon_{\mathrm{Nd}}$ of shallower crust MKD13 is interpreted as reflecting progressive closure of Indonesian Seaway in the Miocene, while the deep western boundary current sourced from the Southern Pacific may have dominated Nd isotopes of deeper crust MDD53 during the same time interval. The lack of Nd isotopic variation of MKD13 in the Pliocene indicates that there were no changes in $\mathrm{Nd}$ sources in shallower waters and the final restriction between the Indian and Pacific may have only occurred since then. Therefore the observed large shift to more radiogenic Nd isotopes of MDD53 in the Pliocene should not be resulted from changes in vertical input from shallower to deeper water. Instead, a decreased ventilation of deep southern component current along the studied water depth range $(\sim 2700 \mathrm{~m})$ may have continued in the Pliocene.
\end{abstract}

North Pacific, ferromanganese crust, Indonesian Seaway, Nd isotopes, late Cenozoic

Citation: $\quad$ Hu R, Chen T Y, Ling H F. Late Cenozoic history of deep water circulation in the western North Pacific: Evidence from Nd isotopes of ferromanganese crusts. Chin Sci Bull, 2012, 57: 4077-4086, doi: 10.1007/s11434-012-5322-9

As the end of great oceanic conveyor, the deep western North Pacific is likely an essential part in understanding the dynamics of global thermohaline circulation. According to the water properties studies [1-5], the modern oxygen-rich Lower Circumpolar Deep Water (LCDW >3500 m) bifurcates at the equatorial central Pacific basin. The western branch of it flows northwest toward Mariana arc below water depth of $\sim 4000 \mathrm{~m}$ and the eastern branch flows across the Wake Passage and then into the central North Pacific. On the other hand, the Upper Circumpolar Deep Water (UCDW) at low latitudes in the Pacific, flows along 3000$3500 \mathrm{~m}$ depth. Its main route proceeds westward through

*Corresponding author (email: hfling@nju.edu.cn) the north of Pupua New Guinea and then flows into the Philippine Sea (Figure 1). However, since our knowledge about the past deep ventilation history of the western North Pacific is actually still very limited, it is not clear whether such water mass distribution changed or not in the past, e.g. during the closing of the Indonesian gateway.

Neodymium isotopes from authigenic sediments, e.g. ferromanganese crusts, have been proven a useful tracer to monitor the pattern of ocean circulation [6-12]. The average residence time of $\mathrm{Nd}$ in the global ocean $(\sim 300$ to $\sim 600 \mathrm{a})$ which is shorter than the ocean mixing time $(\sim 1500$ a) prevents its complete homogenization and makes $\mathrm{Nd}$ isotopic signals of different water masses distinguishable throughout the ocean $[8,13]$. In the deep North Pacific, although $\mathrm{Nd}$ 


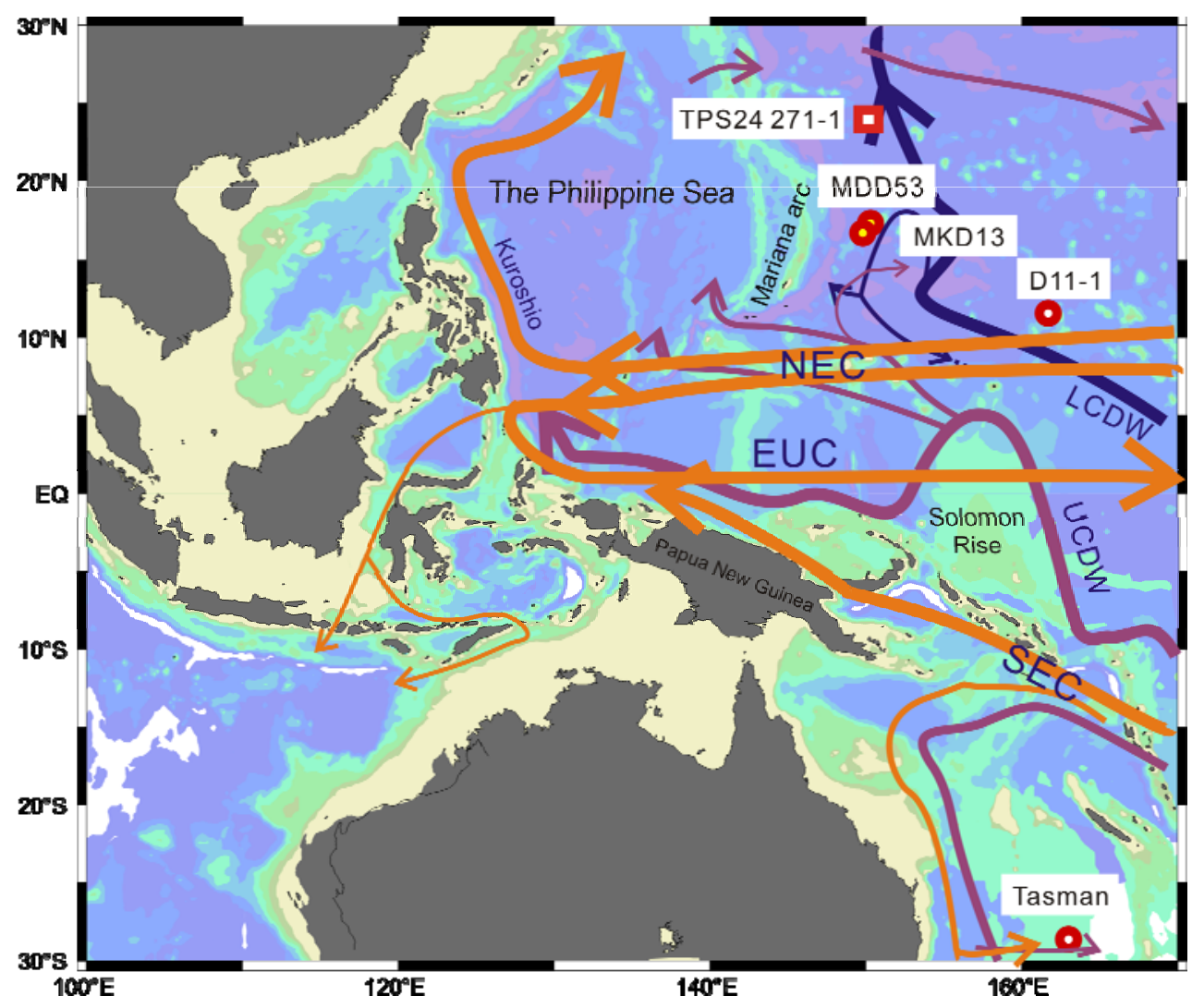

Figure 1 Map of the western North Pacific, showing the location of ferromanganese crusts (MKD13, MDD53, D11-1 [6], Tasman [19]) and the schematically major currents in this area [5,20]. Also shown is a modern seawater profile TPS24 271-1 [14]. Orange lines represent surface and intermediate currents $(<1500 \mathrm{~m})$; purplish red lines represent upper parts of southern component water $(\sim 2000-3500 \mathrm{~m})$; deep blue lines represent lower parts of southern component water $(>4000 \mathrm{~m})$. NEC: North Equatorial Current; EUC: Equatorial Undercurrent; SEC: South Equatorial Current; UCDW: Upper Circumpolar Deep Water; LCDW: Lower Circumpolar Deep Water.

isotopic compositions vary within a small range, they are far from homogenous, making $\mathrm{Nd}$ isotopes still a powerful tool to trace both modern and ancient water masses [6,14-16]. The ferromanganese crusts widely distributed in central and North Pacific are good archives to record past and presentday deep ocean circulation. A large number of crust samples have been collected around the area during several Chinese scientific cruises. This paper focuses on the radiogenic $\mathrm{Nd}$ isotope evolution of the deep western North Pacific in order to reveal past oceanographic changes in this area.

Ling et al. [6,9] found that $\varepsilon_{\mathrm{Nd}}$ values of crusts gradually increased with time based on analyses of $\mathrm{Nd}$ isotopic composition of several ferromanganese crusts in central North Pacific, indicating the increasing influence of more radiogenic $\mathrm{Nd}$ from arc source. $\varepsilon_{\mathrm{Nd}}$ values of crusts have increased significantly especially from the past $15 \mathrm{Ma}$, but the cause of the change is not fully unclosed yet. A crucial point related to the problem is how to discriminate the changes of weathering input from those of deep water circulation. Traditionally, paleoceanographic researches based on $\mathrm{Nd}$ isotopes usually recovered only one record at one location, which lacked depth-related information $[6,9,10,17,18]$. Since deep water $\mathrm{Nd}$ isotopic composition may vary as a result of changes in weathering input, sediment-seawater exchange, and/or deep water circulation, it would be somewhat difficult to distinguish between changes in Nd sources and oceanic circulation at a specific location with the traditional approach. This study investigates the deep water paleocirculation changes east of the Mariana arc using two Nd isotopic profiles of ferromanganese crusts recovered respectively from 1530 and $2700 \mathrm{~m}$ depths (Figure 1), which would help to constrain changes in $\mathrm{Nd}$ sources and water circulation. These two records traced the evolution of water mass mixing between the North Pacific deep water and inflowing southern component water, and thus provided important information on past deep water circulation in the western North Pacific.

\section{Materials and methods}

Both ferromanganese crusts in this study, MDD53 $\left(17^{\circ} 26^{\prime} 34^{\prime \prime} \mathrm{N}\right.$, $150^{\circ} 17^{\prime} 18^{\prime \prime} \mathrm{E}, 121 \mathrm{~mm}$ thick, water depth $\sim 2700 \mathrm{~m}$ ) and MKD13 (16 $51^{\prime} 8^{\prime \prime} \mathrm{N}, 149^{\circ} 47^{\prime} 55^{\prime \prime} \mathrm{E}, 80 \mathrm{~mm}$ thick, water depth: $1530 \mathrm{~m}$ ) were dredged near Mariana arc in western North Pacific by the State Oceanic Administration of China. 
MDD53 has a dense tabular feature with relatively smooth surface, whereas MKD13 has a more porous feature with a rough and micro-botryoidal surface.

Dating ferromanganese crusts has always been complicated. Each dating method used before, such as U series nuclide ${ }^{230} \mathrm{Th}$, Be isotopes, biostratigraphy, magnetostratigraphy, Os isotope stratigraphy and empirical Co equation, has its limits applied to ferromanganese crusts [8,21,22]. The $\mathrm{U}$ series nuclide ${ }^{230} \mathrm{Th}$, which is the most precise method to estimate growth rates, is restricted to about the last $400 \mathrm{ka}$ owing to its short half-life (75 ka) and thus can only date the very shallow surface part of crusts [23-25]. The sparse and incomplete nanofossils preserved in the crusts make biostratigraphy a difficult dating method, resulting in poorly constrained results and discontinuous ages [26,27]. Constrained by complicated demagnetization technique and sample preparation, magnetostratigraphic dating is difficult to be widely applied [28,29]. Considering that crusts can record the well-constrained Cenozoic seawater Osmium isotope evolution, attempts have been made to determine the age of each crust layer by matching Os isotope record of crust to that of coeval seawater. The ${ }^{187} \mathrm{Os} /{ }^{188}$ Os seawater curve is characterized by gradual increase as a whole since late Cretaceous with two distinguished negative spikes at $\sim 65.5$ and $\sim 34.5 \mathrm{Ma}$, which can be regarded as two anchor points in the Os isotope stratigraphy. The former one may be related to meteor impacts at the K-T boundary [30] and the latter one is probably associated with weathering of an ultramafic magma event and an increased influx of extraterrestrial particles to the Earth in the late Eocene [31]. Therefore the Os isotope stratigraphy is more effective in dating crusts throughout the Cenozoic [32-36]. Since there are no distinguished Os isotope minimum events in the time scale of this study, it will be difficult to date the crusts by fitting the Os isotope curves.

${ }^{10} \mathrm{Be}$ dating method is considered to be relatively accurate in time scale of this study. However, such method can only cover at most the last $\sim 10 \mathrm{Ma}$ and have to extrapolate the age model beyond $10 \mathrm{Ma}[6,37,38]$. Unfortunately, ${ }^{10} \mathrm{Be}$ analysis is not available to us. Another often used method to calibrate the ages of crusts in Cenozoic is based on the empirical Co-flux model [9,39-46]. Co is incorporated into ferromanganese crusts from the water column by surface adsorption on hydrous $\mathrm{MnO}_{2}$ and colloidal Mn-oxyhydroxide phase. When Co is scavenged, the oxidation of $\mathrm{Co}^{2+}$ to $\mathrm{Co}^{3+}$ makes Co chemically stable [47,48], resulting in nearly constant flux of Co into crusts during the crust formation [39], if the content of Co in seawater is invariable and the distribution coefficient of $\mathrm{Co}$ in seawater and crusts is unaltered with time [40]. Co content is thus a good proxy to estimate the age of crust layers. Growth rates of the crusts are negatively correlated with the content of Co, i.e. the growth rate of crusts is higher when its Co concentration is lower [39]. Results of empirical Co-flux model are reported to be in good agreement with ${ }^{10} \mathrm{Be}$ dating results for
Pacific crusts [49] and the study of Ling et al. [9] who showed that Co-flux model based ages of crusts without hiatus and phosphatization are consistent with the ages indicated by the $\mathrm{Os}$ and $\mathrm{Pb}$ isotopic patterns. So we can estimate the age of crusts without hiatus or phosphatization by the method of empirical Co-flux model. Based on Co contents of both crusts determined using electron microprobe, age estimates for the two crusts are obtained using the following cobalt calculation models.

Puteanus [50] proposed that Co absorbed onto the Mnoxide phase in older layers would be dissolved due to the infiltration of the ferromanganese crust with $\mathrm{Ca}$ - and phosphate-rich pore water. In order to estimate the growth rate, the primary Co content of the phosphatized older crust generation has to be calibrated. Considering the loss of Co in the phosphatized older layers of crusts in Pacific and according to the negative correlation between the $\mathrm{Mn} / \mathrm{Co}$ ratio and the phosphate content, the primary Co content can be calculated by [41]:

$$
\begin{gathered}
\mathrm{Co}^{(x)^{\prime}}=\mathrm{Co}^{(x) \mathrm{m}}\left[\mathrm{Mn} / \mathrm{Co}^{(x)}\right] /\left[\mathrm{Mn} / \mathrm{Co}^{(\mathrm{b})}\right], \\
\text { if }\left[\mathrm{Mn} / \mathrm{Co}^{(x)}\right] /\left[\mathrm{Mn} / \mathrm{Co}^{(\mathrm{b})}\right]>1, \\
\mathrm{Co}^{(x)^{\prime \prime}}=\mathrm{Co}^{(x)^{\prime}} /(1-0.05 \Delta \mathrm{P}),
\end{gathered}
$$

where $\mathrm{Co}^{(x) \mathrm{m}}$ and $\mathrm{Co}^{(x)^{\prime}}$ stand for measured and corrected $\mathrm{Co}$ concentration, respectively, in layer $x$ of the older crust generation with phosphate dilution; $\mathrm{Mn} / \mathrm{Co}^{(x)}$ stands for $\mathrm{Mn} /$ Co ratio measured in layer $x$ of the older crust generation; and $\mathrm{Mn} / \mathrm{Co}^{(\mathrm{b})}$ stands for $\mathrm{Mn} / \mathrm{Co}$ ratio measured of the boundary layers between the younger and older crust generation; $\Delta \mathrm{P}$ stands for difference between the apatite fraction of the older crust of layer $x$ and the average value of the younger crust generation; $\mathrm{Co}^{(x)^{\prime \prime}}$ stands for double-corrected Co concentration of the layer $(x)$ of the older crust generation.

Manheim and Lane-Bostwick [40] presented that the growth rate of Co-poor crusts can be estimated by:

$$
R=0.68 /[w(\mathrm{Co})]^{1.67},
$$

where $R$ stands for growth rate in $\mathrm{mm} \mathrm{Ma}^{-1}$; and $w(\mathrm{Co})$ stands for Co concentration in percent. The weight of detrital sediments in the samples should be less than $0.0012 \%$.

In this study, the elemental contents of crusts are analyzed using a JXA-8100 electron microprobe at State Key Laboratory for Mineral Deposits Research, Nanjing University. In order to prevent splintering when cutting the crusts, crusts studied were fixed using epoxy resins in vacuum drier at $40^{\circ} \mathrm{C}$, and then cut into slabs $(\sim 8 \mathrm{~cm} \times 4 \mathrm{~cm} \times 2 \mathrm{~cm})$ perpendicular to the growth layers. Then the slabs were polished, washed and dried below $50^{\circ} \mathrm{C}$, and finally coated with carbon powder for electron microprobe analysis. Contents of $\mathrm{Mn}, \mathrm{Fe}, \mathrm{Si}, \mathrm{Al}, \mathrm{P}, \mathrm{Ca}, \mathrm{Sr}, \mathrm{Ni}, \mathrm{Cu}$ and $\mathrm{Co}$ are analyzed and the analytical condition is as follows: An accelerating voltage of $15 \mathrm{kV}$, a beam current of $20 \mathrm{nA}$ and analyzed points 
with $2 \mu \mathrm{m}$ spot diameter.

Sub-samples with typical sample sizes of $\sim 10 \mathrm{mg}$ for neodymium $(\mathrm{Nd})$ isotope analyses were taken every $1-5 \mathrm{~mm}$ from the counterpart slab cut apart for electron microprobe analysis. Neodymium isotope measurement was carried out at the State Key Laboratory for Mineral Deposits Research, Nanjing University, using $\mathrm{LN}$ resin and $\mathrm{HCl}$ leaching for the chemical separation of Nd. Neodymium measurements were performed with a Finnigan Triton thermal ionization mass spectrometer (TIMS). ${ }^{143} \mathrm{Nd} /{ }^{144} \mathrm{Nd}$ ratios were normalized to ${ }^{146} \mathrm{Nd} /{ }^{144} \mathrm{Nd}=0.7219$ to correct the instrumental mass fractionation during measuring. Repeated analyses of the Nd standard JNdi-1 yielded $0.512121 \pm 2$ ( $2 \sigma$ external standard deviation, $n=15$ ).

\section{Results}

The electron microprobe analysis results show that phosphatization occurred below the depth of $63.0 \mathrm{~mm}$ in crust MDD53, whereas crust MKD13 is not phosphatized at any time since Miocene. Crust MKD13 has low Co content with an average of $0.40 \%$ and yields an age of 30.0 Ma for the crust bottom by using the model of Manheim and Lane- Bostwick (eq. (3)) [40]. Crust MDD53 also has low Co content in the non-phosphatization parts (average of $0.69 \%$ ), and the Co content of the phosphatized parts is corrected using eqs. (1) and (2) of Puteanus and Lane-Bostwick [41] before age estimated by using model of Manheim and Lane-Bostwick (eq. (3)) [40], which yields a bottom age of $72.2 \mathrm{Ma}$ that is similar to the ages of the central North Pacific crusts [9].

Dating results based on cobalt constant flux model are presented in Figure 2 and Table 1. Crust MKD13 has an overall growth rate about $2.67 \mathrm{~mm} / \mathrm{Ma}$. During the past $\sim 20$ $\mathrm{Ma}$, the average growth rate is about $2.80 \mathrm{~mm} / \mathrm{Ma}$ with relatively small variation. MDD53 can be divided into two sections with obviously different growth rates, the Quaternary section with growth rate similar to MKD13 and the
Neogene section with much slower growth rates $(\sim 0.9$ $\mathrm{mm} / \mathrm{Ma})$. Crust MDD53 has an overall growth rate about $1.66 \mathrm{~mm} / \mathrm{Ma}$. During the past $20 \mathrm{Ma}$, the average growth rate is about $1.18 \mathrm{~mm} / \mathrm{Ma}$.

As our major concern is the evolution of deep circulation in the western North Pacific associated with the progressive closure of Indonesian seaway, here we only presented the $\mathrm{Nd}$ isotopes since the early Miocene ( 20 Ma). Earlier $\mathrm{Nd}$ isotopic records, which may be complicated by accumulated age uncertainties and plate-movement-associated factors, are out of our scope and thus will not be discussed in this paper.

Neodymium isotope time series for crusts MDD53 and MKD13 are shown in Figure 3 and Table 1. Apparently, they display very different patterns of evolution. Over the Miocene, while MKD13 became progressively more radiogenic in $\mathrm{Nd}$ isotopes $\left(\varepsilon_{\mathrm{Nd}}-4.5\right.$ to -3.2$)$, MDD53 was relatively stable in $\mathrm{Nd}$ isotopes $\left(\varepsilon_{\mathrm{Nd}}-4.1\right.$ to -4.8$)$. In the Pliocene, a remarkable increase in $\varepsilon_{\mathrm{Nd}}$ values is observed in MDD53 (-4.6 to -3.2$)$ but not in MKD13. Thus it is interesting to note that the two $\mathrm{Nd}$ isotopic records were decoupled as a whole.

Under the age model mentioned above, the increase of $\varepsilon_{\mathrm{Nd}}$ values of crust MKD13 mainly occurred in Miocene, and then stayed stable in Pliocene and Quaternary, while crust MDD53 saw an abrupt increase in its $\varepsilon_{\mathrm{Nd}}$ values in Pliocene. However, considering that the ages calculated from the empirical Co contents model which could not discover sedimentary hiatus may have errors and that such errors may have caused the discrepancy of the $\mathrm{Nd}$ isotope evolutions of two crusts, the reliability of the ages of both the crusts need to be further constrained. First, by comparing the $\mathrm{Nd}$ isotope time series of this study with the nearby $\mathrm{Nd}$ isotope evolution records, we found that the evolution pattern of $\mathrm{Nd}$ isotopes in MKD13 is all the way similar to the nearby crust D11-1 at similar water depth $\left(11^{\circ} 38^{\prime} 54^{\prime \prime} \mathrm{N}\right.$, $\left.161^{\circ} 40^{\prime} \mathrm{E}, 1700 \mathrm{~m}\right)$ [6], which supports the age results of MKD13 (Figure 4(a)). Second, the distinct increase in $\varepsilon_{\mathrm{Nd}}$ of
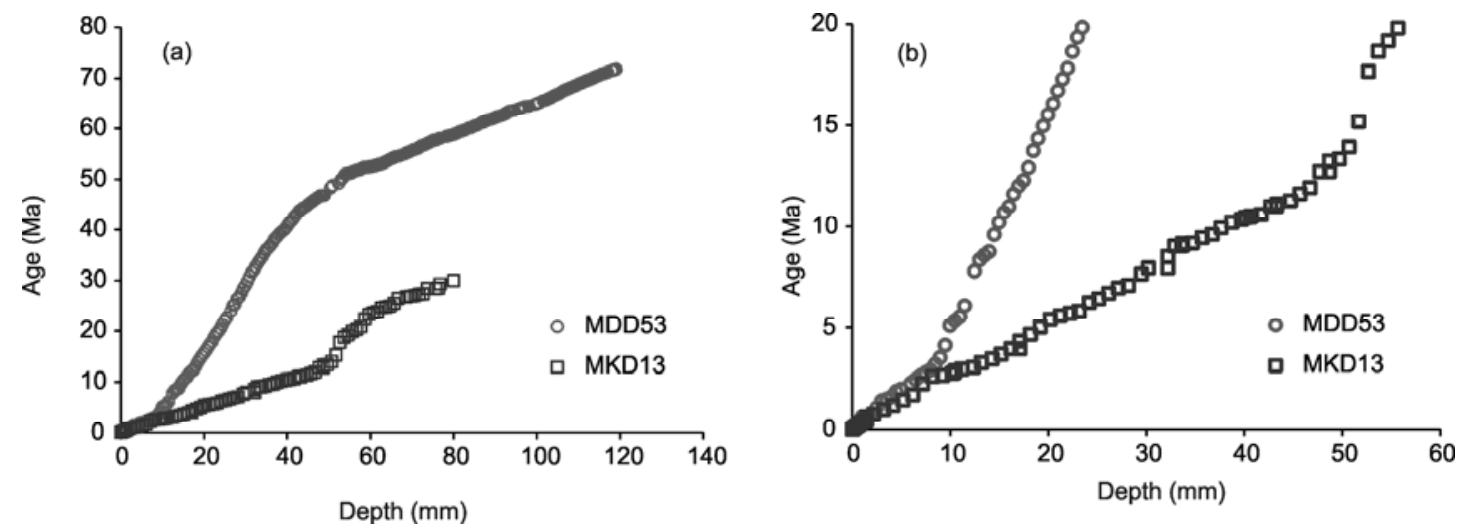

Figure 2 Ages of ferromanganese crusts derived from cobalt constant flux model versus depth beneath surface of the crusts. (a) The overall growth rates of crusts MDD53 and MKD13; (b) the growth rates of crusts MDD53 and MKD13 in the past 20 Ma. 
Table $1 \mathrm{Nd}$ isotopic compositions for ferromanganese crusts MKD13 and MDD53 from the western North Pacific

\begin{tabular}{|c|c|c|c|c|}
\hline Sample & Depth $(\mathrm{mm})$ & Age (Ma) & ${ }^{143} \mathrm{Nd} /{ }^{144} \mathrm{Nd}(2 \sigma)$ & $\varepsilon_{\mathrm{Nd}}^{\mathrm{a})}$ \\
\hline MKD13-0 & 0 & 0 & $0.512471 \pm 2$ & -3.26 \\
\hline MKD13-1 & 1.0 & 0.4 & $0.512470 \pm 2$ & -3.28 \\
\hline MKD13-2 & 3.0 & 1.0 & $0.512471 \pm 3$ & -3.26 \\
\hline MKD13-3 & 5.0 & 1.3 & $0.512479 \pm 6$ & -3.10 \\
\hline MKD13-4 & 7.0 & 2.2 & $0.512467 \pm 6$ & -3.34 \\
\hline MKD13-5 & 10.0 & 2.7 & $0.512472 \pm 6$ & -3.24 \\
\hline MKD13-6 & 14.5 & 3.3 & $0.512472 \pm 5$ & -3.24 \\
\hline MKD13-7 & 17.0 & 3.9 & $0.512473 \pm 6$ & -3.22 \\
\hline MKD13-8 & 21.0 & 5.5 & $0.512470 \pm 2$ & -3.28 \\
\hline MKD13-9 & 24.0 & 6.2 & $0.512458 \pm 6$ & -3.51 \\
\hline MKD13-10 & 27.0 & 6.9 & $0.512447 \pm 2$ & -3.73 \\
\hline MKD13-11 & 31.0 & 7.9 & $0.512436 \pm 1$ & -3.94 \\
\hline MKD13-12 & 35.0 & 9.3 & $0.512431 \pm 1$ & -4.04 \\
\hline MKD13-13 & 39.0 & 10.3 & $0.512420 \pm 2$ & -4.25 \\
\hline MKD13-14 & 43.0 & 11.0 & $0.512414 \pm 2$ & -4.37 \\
\hline MKD13-15 & 47.0 & 12.2 & $0.512409 \pm 2$ & -4.47 \\
\hline MKD13-16 & 51.0 & 14.5 & $0.512400 \pm 2$ & -4.64 \\
\hline MKD13-17 & 56.0 & 20.0 & $0.512408 \pm 4$ & -4.46 \\
\hline MDD53-0 & 0 & 0 & $0.512457 \pm 2$ & -3.53 \\
\hline MDD53-1 & 2.0 & 0.6 & $0.512446 \pm 2$ & -3.75 \\
\hline MDD53-2 & 3.8 & 1.6 & $0.512447 \pm 1$ & -3.73 \\
\hline MDD53-3 & 5.5 & 2.1 & $0.512472 \pm 3$ & -3.24 \\
\hline MDD53-4 & 6.5 & 2.5 & $0.512435 \pm 4$ & -3.96 \\
\hline MDD53-5 & 9.5 & 4.1 & $0.512403 \pm 8$ & -4.58 \\
\hline MDD53-6 & 10.5 & 5.3 & $0.512421 \pm 2$ & -4.23 \\
\hline Duplicate & 10.5 & 5.3 & $0.512426 \pm 2$ & -4.14 \\
\hline MDD53-7 & 11.5 & 6.1 & $0.512421 \pm 3$ & -4.23 \\
\hline MDD53-8 & 12.5 & 7.8 & $0.512411 \pm 4$ & -4.43 \\
\hline MDD53-9 & 13.5 & 8.6 & $0.512392 \pm 2$ & -4.80 \\
\hline MDD53-10 & 15.5 & 10.7 & $0.512412 \pm 2$ & -4.41 \\
\hline MDD53-11 & 17.5 & 12.3 & $0.512403 \pm 3$ & -4.58 \\
\hline MDD53-12 & 20.5 & 16.1 & $0.512392 \pm 2$ & -4.80 \\
\hline
\end{tabular}

a) Measured ${ }^{143} \mathrm{Nd} /{ }^{144} \mathrm{Nd}$ of crusts samples are presented as $\varepsilon_{\mathrm{Nd}}$ values in Table 1. $\varepsilon_{\mathrm{Nd}}$ values have been calculated as $\varepsilon_{\mathrm{Nd}}=\left[\left({ }^{143} \mathrm{Nd} /{ }^{144} \mathrm{Nd}\right)_{\text {sample }} /\left({ }^{143} \mathrm{Nd} /\right.\right.$ $\left.\left.{ }^{144} \mathrm{Nd}\right)_{\text {CHUR }}-1\right] \times 10^{4}$, where $\left({ }^{143} \mathrm{Nd} /{ }^{144} \mathrm{Nd}\right)_{\text {sample }}$ means the ${ }^{143} \mathrm{Nd} /{ }^{144} \mathrm{Nd}$ ratio of the sample, and $\left({ }^{143} \mathrm{Nd} /{ }^{144} \mathrm{Nd}\right)_{\mathrm{CHUR}}$ is that of the modern Chondritic Uniform Reservoir (i.e. 0.512638 [51]). Since the time scale of crusts this study focuses $(\sim 20 \mathrm{Ma})$ is relatively very short to the half-life time of ${ }^{147} \mathrm{Sm}$ $\left(1.06 \times 10^{11}\right.$ a [52]), and ${ }^{147} \mathrm{Sm} /{ }^{144} \mathrm{Nd}$ of crusts is generally low ( 0.11) [6], ${ }^{143} \mathrm{Nd}$ generated by the decay of ${ }^{147} \mathrm{Sm}$ during this time is insignificant compared with that caused by the seawater variation with time, and thus $\left({ }^{143} \mathrm{Nd} /{ }^{144} \mathrm{Nd}\right)_{\text {sample }}$ does not need be corrected by the decay of ${ }^{147} \mathrm{Sm}$. In other words, ${ }^{143} \mathrm{Nd} /{ }^{144} \mathrm{Nd}$ for samples of crusts we measured can represent that of crusts when they formed.

crust MDD53 occurred only in $\sim 0.5 \mathrm{~cm}$ intervals of the crust (from 9.5 to $5.5 \mathrm{~mm}$, see Table 1). If this increase was as gradual as MKD13 or D11-1 over a time scale of more than $10 \mathrm{Ma}$, this would yield a growth rate for MDD53 of less than $0.5 \mathrm{~mm} / \mathrm{Ma}$, an extremely low growth rate never reported for hydrogenic ferromanganese crusts (the reported growth rates are usually $1-15 \mathrm{~mm} / \mathrm{Ma}[37,41,54])$. In addition,

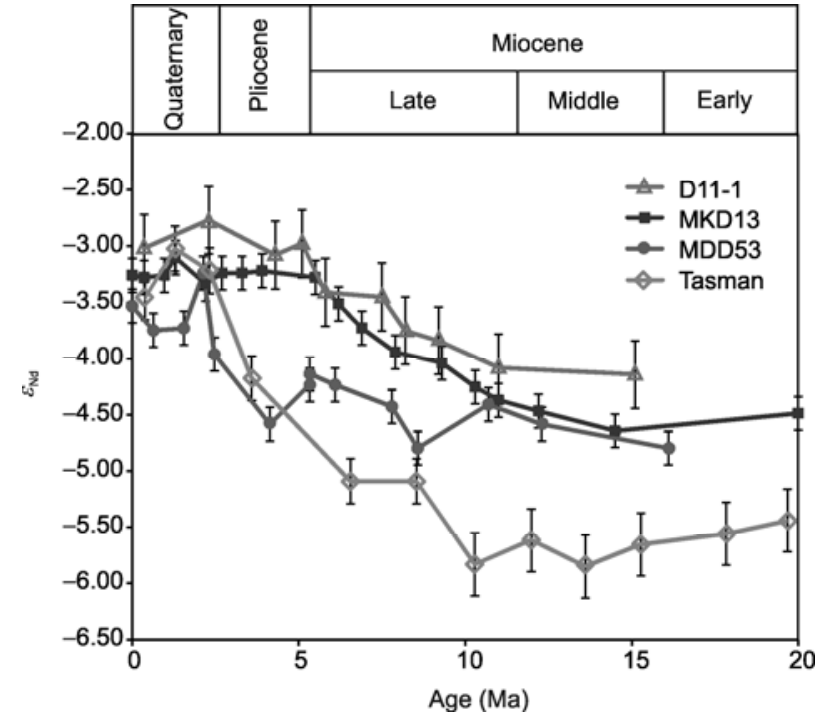

Figure 3 Plot of $\varepsilon_{\mathrm{Nd}}$ values versus age of the Pacific ferromanganese crusts (Nd isotope data for D11-1 is from Ling et al. [6], and the age data is based on ${ }^{10} \mathrm{Be}$ dating and minorly revised according to $\mathrm{Tl}$ isotope stratigraphy [53]; data for Tasman is from van de Flierdt et al. [19]).

the specimen of crust MDD53 shows a smooth growth pattern without clear growth hiatus. Finally, Nd isotopes extracted from the carbonate fraction of site $807\left(3^{\circ} 4^{\prime} \mathrm{N}\right.$, $156^{\circ} 4^{\prime} \mathrm{E}, 2815 \mathrm{~m}$ ) [55], which located directly east of the Indonesian islands, displayed a similar evolution pattern as that of crust MDD53 (Figure 4(b)), i.e. an abrupt increase in $\varepsilon_{\mathrm{Nd}}$ during the Pliocene and a small overall shift in Nd isotopes from $\sim 15$ to $5 \mathrm{Ma}$. However, Nd isotopes of site 807 are systematically more radiogenic (about 1 unit in $\varepsilon_{\mathrm{Nd}}$ higher) than those of MDD53, which may represent local addition from boundary sediments-seawater exchange to the water [56,57]. Nevertheless, this offset has to be further understood in future studies. However, the two evolution patterns are not all the way matched each other. An obvious difference occurred since the latest $5 \mathrm{Ma}$, that the maximum $\varepsilon_{\mathrm{Nd}}$ value of Site 807 appeared in Pliocene ( 3.2 Ma), while MDD53 appeared in early Quaternary $(\sim 2.1 \mathrm{Ma})$. Such discrepancy may occur due to the error of the Co-flux model age results of this study, which may reach as large as 1-2 Ma but may not affect the discussion on long-time Nd isotope evolution since early Miocene. In fact, the two Nd isotopic evolution patterns revealed by this study are inconsistent (Figure 3) no matter how to slightly adjust the ages of both crusts to eliminate errors in the age estimates.

\section{Discussion}

\subsection{Closing of Indonesian gateway to surface- and mid-water exchange and dominance of SCW in deep western North Pacific over the Miocene}

In the early and middle Miocene, crusts MDD53 and MKD13 

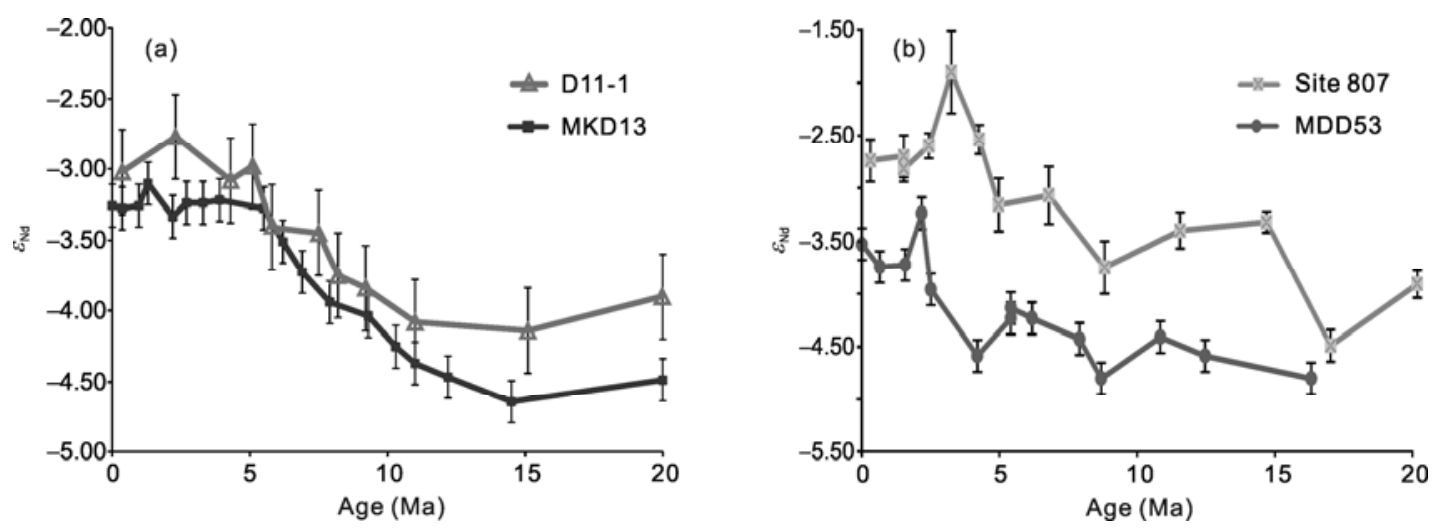

Figure 4 Comparison between $\varepsilon_{\mathrm{Nd}}$ time series of ferromanganese crusts MKD13 and MDD53 (this study) and the nearby Nd isotope records. (a) Shallower crust MKD13 and D11-1 (Nd isotope data for D11-1 is from Ling et al. [6], and the age data is based on ${ }^{10} \mathrm{Be}$ dating and minorly revised according to Tl isotope stratigraphy [53]). (b) Deeper cust MDD53 and carbonate fraction of the western equatorial sediment core Site 807 [55].

had similar $\varepsilon_{\mathrm{Nd}}$ values (-4.0 to -4.8$)$ (Figure 3), which were typical of modified southern component water signature [16]. While overall Nd isotopes of crust MDD53 remained stable, $\varepsilon_{\mathrm{Nd}}$ of crust MKD13 increased by more than $1 \varepsilon_{\mathrm{Nd}}$ unit over the Miocene. A possible explanation for that would be an enhanced supply of $\mathrm{Nd}$ from arc materials since 15-20 Ma, through the way of either boundary exchange or surface weathering. However, evidence from $\mathrm{Pb}$ isotopes was proposed against a progressive increase in Pacific arc erosion over the past $10 \mathrm{Ma}$ [19]. In addition, the most abrupt increase of Cenozoic pacific arc production actually occurred during the Pliocene and Quaternary, not the Miocene [58-61]. Thus this enhancement of radiogenic weathering flux alone is not a satisfactory interpretation for the observed increase in $\varepsilon_{\mathrm{Nd}}$ of crust MKD13. One may also argue that a decrease in supply of SCW via the southwest Pacific to the studied area could generate the observed isotopic shifts in MKD13. However, this is not supported by the relatively stable $\varepsilon_{\mathrm{Nd}}$ values of Southwest Pacific crust Tasman with a similar water depth $\left(28^{\circ} 34.0^{\prime} \mathrm{S}, 163^{\circ} 00.0^{\prime} \mathrm{E}\right.$, $\sim 1700 \mathrm{~m}$, Figure 3, [19]) during the early to middle Miocene. We therefore suggest that the low $\varepsilon_{\mathrm{Nd}}$ values of MKD13 in the early Miocene indicated the presence of direct supply of less radiogenic $\mathrm{Nd}$ isotopic southern component surface and middle water [55] via the Indonesian gateway. Such scenario was also proposed by Meynadier et al. [62]. In fact, Gourlan et al. [55] inferred that a shallow and intermediate current from Indian to Pacific probably existed before 14 $\mathrm{Ma}$ in the southern part of the seaway. Then the subsequent increase in $\varepsilon_{\mathrm{Nd}}$ of shallower crust MKD13 reflected the gradually diminishing supply of less radiogenic water from the Indian Ocean to the western North Pacific through the Indonesian gateway.

Given the above explanation for MKD13, it seems counterintuitive that the overall unradiogenic signal of crust MDD53 in deeper water depth varied little during the same period. However, this should not be surprising if supposed deep water exchange through the Indonesian Gateway had already closed before the early Miocene and thus exchange only occurred in surface- and mid-water in the early Miocene. Reconstruction of this gateway evolution has been studied by different approaches, such as plate tectonic model, bio-stratigraphic comparison, and stable isotopes $(\mathrm{C}, \mathrm{O})$ of foraminifera tests. A comprehensive study of Cenozoic geological and plate tectonic evolution at the Indonesian gateway region was made by Hall [60]. At present, Indonesian Gateway is only open for very limited surficial water exchange between Pacific and India ocean. However, it is generally agreed that a wide Australia-Asia gap existed before $25 \mathrm{Ma}$, when deep water exchange between the Indian and Pacific could have occurred. At about $25 \mathrm{Ma}$, a major reorganization of plate boundaries was initiated by collision between the New Guinea Block and the SE Asia Block $[56,59,60]$. This may have effectively restricted the deep oceanic currents $(>2000 \mathrm{~m})$ across the seaway. Such a scenario is supported by divergent deep water $\delta^{18} \mathrm{O}$ evolution on both sides of the gateway in the early Miocene [63]. Therefore it is reasonable to infer that further closing process of the Indonesian Seaway from 10 to $15 \mathrm{Ma}$ had only influence on $\mathrm{Nd}$ isotopes of shallow to mid-water (crust MKD13) but not on those of the deep water (crust MDD53).

In the modern central North Pacific, overall $\varepsilon_{\mathrm{Nd}}$ of seawater in depth interval between 1000 and $5000 \mathrm{~m}$ vary within a small range ( -3 to -5$)$. Specifically, a modern seawater profile (Figure 1, TPS 24 271-1 [14]) in the region of this study revealed little $\mathrm{Nd}$ isotopic difference between water depths of 1530 and $2700 \mathrm{~m}$. The $\varepsilon_{\mathrm{Nd}}$ values of the surface scrapings of crusts MKD13 and MKD53 are also similar. Given such homogeneity in the modern western North Pacific, a $\varepsilon_{\mathrm{Nd}}$ difference of more than 1 unit between crusts MKD13 and MKD53 before $~ 5$ Ma should have significant implications, i.e. the ocean circulation pattern at that time was different from that of the present. Unradiogenic continental $\mathrm{Nd}$ from marginal seas near China is not likely a contributor to the observed less radiogenic feature of the late Miocene to Pliocene part of crust MDD53. The 
modern Kuroshio waters originating from the North Pacific Tropical Water (NPTW), for example, have very unradiogenic $\mathrm{Nd}$ [64]. If these sources indeed supplied significant unradiogenic $\mathrm{Nd}$ to crust MDD53, they would have also affected $\mathrm{Nd}$ isotopic records of shallower crust MKD13. In fact, crust MKD13 became radiogenic more quickly than crust MDD53 from early to middle Miocene (Figure 3). Thus we believe that low $\varepsilon_{\text {Nd }}$ values of crust MDD53 before $\sim 5 \mathrm{Ma}$ reflected intensified southern component deep water contribution along the western Pacific and $\mathrm{Nd}$ isotopic compositions of crust MDD53 revealed dominance of the deep western boundary current sourced from the Pacific Southern ocean (e.g. $\varepsilon_{\mathrm{Nd}}=-4.5$ to -5.0 [15]) along the water depth of crust MDD53 over the Miocene. Also noteworthy is that evolution of $\mathrm{Nd}$ isotopes of crust MDD53 is characterized by wave-like excursions in the Miocene (Figure 3 ). These fluctuations should not be a result of arc weathering input or boundary exchange pulses to the surface western North Pacific, because such fluctuations are not observed in shallower crust MKD13. Nevertheless, $\varepsilon_{\mathrm{Nd}}$ of crust MDD53 in the Miocene were the lowest $\left(\varepsilon_{\mathrm{Nd}}-4.0\right.$ to -5.0$)$ among reported North Pacific crusts from similar water depths [19]. We interpret this as a result of an overall strengthened but fluctuated supply of deep southern component water via the western Pacific boundary to crust MDD53.

\subsection{Development of modern western Pacific deep circulation since the Pliocene}

The final restriction for surface and thermocline water masses exchange between the Pacific and Indian oceans through the Indonesian Gateway is still controversial. Various restriction events were proposed. Kennett et al. [65] interpreted the late Miocene similar assemblages of planktonic foraminifera across the entire tropical Pacific as reflecting the effective closing of the Indonesian Seaway around 8 Ma. In contrast, a switch from the South Pacific to North Pacific surface waters flowing through the seaway into the Indian Ocean, associated with a major Indonesian plates reorganization between 5 and $3 \mathrm{Ma}$, was suggested by Cane and Molnar [66]. Srinivasan and Sinha [67] provided planktonic foraminifera evidence and suggested that the Indonesian Gateway became an effective biogeographic barrier for deep-dwelling planktonic foraminifers only after about $5 \mathrm{Ma}$. The existence of Miocene Indian Ocean Equatorial Jet and its subsequent diminishing between 4-2.5 Ma accompanying the final closure of the Indonesian gateway has also been proposed based on $\mathrm{Nd}$ isotopes study in marine sediments [55]. The data of this study supports that the final restriction between the Indian and Pacific may have only occurred since the Pliocene, as can be seen in Figure 3 that shallower crust MKD13 shows little Nd isotopic variations after $~ 5$ Ma.

In contrast, deeper crust MDD53 shows a remarkable increase in $\varepsilon_{\mathrm{Nd}}$ in the Pliocene. Possible causes for this could be: (i) changes in $\mathrm{Nd}$ isotopic composition of the circumpolar deep water; (ii) enhanced supply of radiogenic Nd isotopes from the surface and intermediate water; and/or intensified "boundary exchange" [66,67] with volcanic material (i.e. the southwest pacific arcs) along the path of UCDW (Figure 1); (iii) decreased supply of southern component deep water.

Previous studies have already showed that $\mathrm{Nd}$ isotopes of southern circumpolar deep water are relatively stable during this period, and therefore changes in $\mathrm{Nd}$ isotopes of southern circumpolar deep water could be ruled out as a possible scenario. Only if an increased supply of $\mathrm{Nd}$ from arcs did not alter much the overall $\mathrm{Nd}$ isotopic composition of the North Pacific surface and intermediate water, $\mathrm{Nd}$ isotopes of crust MKD13 could be expected as less sensitive than crust MDD53 to arc weathering flux. Otherwise, an enhanced radiogenic weathering flux in the Pliocene could have a consistent effect on both crusts records. The following reasons indicate that this assumption may not be tenable. First, arc sediments typically show positive $\varepsilon_{\mathrm{Nd}}$ values [19]. Accordingly, if arc erosion indeed gradually increased in supplying radiogenic $\mathrm{Nd}$ to the studied area, we should expect crust MKD13 $(1530 \mathrm{~m})$ be more sensitive to such influence when that weathering input including sedimentseawater exchange occurring basically in the upper ocean $(<1500 \mathrm{~m})$ is considered. Second, the similar increase of radiogenic $\mathrm{Nd}$ isotopes in the Southwest crust Tasman $\left(28^{\circ} 34.0^{\prime} \mathrm{S}, 163^{\prime \prime} 00.0^{\prime} \mathrm{E}, \sim 1700 \mathrm{~m}\right.$, Figure 3, [19]), which was suggested to reflect a deflection of South Equatorial Current (SEC) rather than weathering input variation, favors possibility of deep circulation reorganization during this period [19]. At the current stage, we could not rule out that intensified deep boundary exchange with volcanogenic $\mathrm{Nd}$ led to the increase in $\varepsilon_{\mathrm{Nd}}$ of crust MDD53 at the early Pliocene. However, the following lines of evidences suggest this scenario is also unlikely. First, the increase in radiogenic $\mathrm{Nd}$ isotopes of crust MDD53 stopped when reaching the isotopic composition of central North Pacific intermediate water, which is also the case for crust Tasman (Figure 3), implying that central North Pacific intermediate water may still be the radiogenic end member for both crusts and no additional radiogenic sources are needed [12]. Second, increase in boundary exchange needs enhanced supply of radiogenic arc sediment from the surface and intermediate water. Again, a correspondent $\varepsilon_{\mathrm{Nd}}$ change in shallower crust MKD13 is not observed. Therefore the two above scenarios $\mathrm{i}$ and ii are both unlikely.

Therefore, scenario iii is the most likely cause for the Pliocene increase in $\varepsilon_{\mathrm{Nd}}$ of deeper crsut MDD53, i.e. a decreased ventilation of unradiogenic deep water at $\sim 2700 \mathrm{~m}$ probably occurred at the early Pliocene. Consequently, a concomitant increase in proportion of radiogenic North Pacific water in the studied region should be expected and lead to increase in $\varepsilon_{\mathrm{Nd}}$ of crust MDD53. The smaller $\varepsilon_{\mathrm{Nd}}$ difference between crusts MDD53 and MKD13 at the Quaternary than before suggests similar $\mathrm{Nd}$ sources since then. Remarkably, the growth rates of the two crusts have been close 
to each other since the Pliocene (Figure 2). A modern nearby seawater profile, TPS $24271-1$, also reveals that typical southern component water signal ( $\varepsilon_{\mathrm{Nd}}$ values of -4.5 to -5.0 ) occurs only at water depths below $4000 \mathrm{~m}$ [14]. As mentioned above, modern UCDW which ventilates the western North pacific at about 3000-3500 m follows the route east of the Solomon Rise (Figure 1), but a large fraction of it does not directly flow into the east Mariana basin [2,5]. Instead, the major route turns westward near Papua New Guinea arc and then flows into the Philippine Sea. However, the flow pattern before $5 \mathrm{Ma}$ might have not been the same like this. There could be a stronger eastern bifurcating current of UCDW that directly ventilated the water surrounding crust MDD53 before $\sim 5 \mathrm{Ma}$. This ventilation may have then diminished in the Pliocene. Nevertheless, the weakening of the local southern ventilation should not necessarily indicate that the total volume transport of deep currents to the North Pacific strengthened or weakened. Unfortunately, the $\mathrm{Nd}$ isotopic data presented here are not explicit in elucidating the cause of deep southern component water ventilation changes. We envisage that changes in bottom topography associated with plate movements and cooling/warming in the high latitudes of the Southern Ocean could regulate the intensity/depth of deep western boundary currents in the studied area. Further works, such as model study, are clearly needed to clarify the mechanism of the circulation changes in the Pliocene western North Pacific. Interestingly, the $\mathrm{Nd}$ isotopic records of southwestern crust Tasman [19] and northwestern crust MDD53 are closely correlated since the early Pliocene, implying that the deep western Pacific circulation may be broadly coupled between both hemispheres when the Indonesian Seaway had been completely restricted.

It is likely that the similarity in $\mathrm{Nd}$ isotopic compositions between the studied two crusts in the Quaternary marked the full development of the modern deep circulation pattern near the Mariana arc. In the surface western North Pacific, the modern circulation pattern is characterized by the final formation of the west Pacific warm pool (WPWP) during 3-4 Ma [68] and the intensification of Kuroshio Current at about 3 Ma [69,70]. Also noteworthy is the indistinguishable $\mathrm{Nd}$ isotopic composition of the equatorial and the Southwestern Pacific deep water over the Quaternary (Figure 3), as well as the convergent trends in $\mathrm{Nd}$ isotopic compositions of these crusts. Hence an overall intensification of western Pacific water masses mixing may have occurred in the Quaternary.

\section{Conclusion}

In this study, we reconstructed the deep water circulation in the western North Pacific since the early Miocene, using Nd isotopic time series of two ferromanganese crusts. These two crusts grew at the same longitude and latitude, but with depth difference of more than $1000 \mathrm{~m}$, allowing us to iden- tify changes in weathering inputs versus past ocean circulation. We propose that relatively strong ventilation of southern component boundary current along the water depth range of deeper crust MDD53 existed from the early to late Miocene. During this time interval, an increase in radiogenic $\mathrm{Nd}$ isotopes of shallower crust MKD13 reflected progressive closure of the Indonesian Seaway to the middle and surface water exchange between the Pacific and Indian Ocean. In accordance with previous studies, the final restriction of the seaway probably occurred in the early Pliocene, which was demonstrated by the invariable nature of $\mathrm{Nd}$ isotopes in crust MKD13 afterwards. On the other hand, an abrupt increase in radiogenic $\mathrm{Nd}$ isotopes of crust MDD53 was notable in the Pliocene, suggesting that a decreased ventilation of the unradiogenic southern component water along the water depth range of crust MDD53 may have happened during this time. The data presented in this study provide a preliminary understanding of the deep western North pacific circulation changes since the Miocene, and also a comparison to the study of past southwestern Pacific circulation based on radiogenic isotopes [19].

This work was supported by the Chinese Association for Research of Oceanic Mineral Resources (DY-115-01-2-2). The authors thank the editors and two anonymous reviewers for their constructive comments, and also they are grateful to Prof. Zhang Wenlan, Chen Xiaoming and Senior Engineer Pu Wei in State Key Laboratory for Mineral Deposits Research for their laboratory assistance.

1 Owens W B, Warren B A. Deep circulation in the northwest corner of the Pacific Ocean. Deep Sea Res Part I, 2001, 48: 959-993

2 Kawabe M, Fujio S, Yanagimoto D. Deep-water circulation at low latitudes in the western North Pacific. Deep Sea Res Part I, 2003, 50: 631-656

3 Kawabe M, Fujio S, Yanagimoto D, et al. Water masses and currents of deep circulation southwest of the Shatsky Rise in the western North Pacific. Deep Sea Res Part I, 2009, 56: 1675-1687

4 Komaki K, Kawabe M. Deep-circulation current through the Main Gap of the Emperor Seamounts Chain in the North Pacific. Deep Sea Res Part I, 2009, 56: 305-313

5 Kawabe M, Fujio S. Pacific ocean circulation based on observation. J Oceanogr, 2010, 66: 389-403

6 Ling H F, Burton K W, O'Nions R K, et al. Evolution of Nd and $\mathrm{Pb}$ isotopes in Central Pacific seawater from ferromanganese crusts. Earth Planet Sci Lett, 1997, 146: 1-12

7 Burton K W, Ling H F, O'Nions R K. Closure of the Central American Isthmus and its effect on deep-water formation in the North Atlantic. Nature, 1997, 386: 382-385

8 Frank M. Radiogenic isotopes: Tracers of past ocean circulation and erosional input. Rev Geophys, 2002, 40: 1-38

9 Ling H F, Jiang S Y, Frank M, et al. Differing controls over the Cenozoic $\mathrm{Pb}$ and $\mathrm{Nd}$ isotope evolution of deepwater in the central North Pacific Ocean. Earth Planet Sci Lett, 2005, 232: 345-361

10 Foster G L, Vance D, Prytulak J. No change in the neodymium isotope composition of deep water exported from the North Atlantic on glacial-interglacial time scales. Geology, 2007, 35: 37-40

11 Zhao K D, Jiang S Y, Zheng X Y, et al. Nd isotope evolution of ocean waters and implications for paleo-ocean circulation (in Chinese). Earth Sci Front, 2009, 16: 160-171

12 Chen T Y, Ling H F, Hu R. Neodymium isotopes distribution and transport in the central North Pacific deep water. Chin Sci Bull, 2011, 56: $2243-2250$ 
13 Albarede F, Goldstein S L. World map of $\mathrm{Nd}$ isotopes in sea-floor ferromanganese deposits. Geology, 1992, 20: 761-763

14 Piepgras D J, Jacobsen S B. The isotopic composition of neodymium in the North Pacific. Geochim Cosmochim Acta, 1988, 52: 13731381

15 Amakawa H, Nozaki Y, Alibo D S, et al. Neodymium isotopic variations in Northwest Pacific waters. Geochim Cosmochim Acta, 2004, 68: 715-727

16 Amakawa H, Sasaki K, Ebihara M. Nd isotopic composition in the central North Pacific. Geochim Cosmochim Acta, 2009, 73: 4705-4719

17 O’Nions R K, Frank M, von Blanckenburg F, et al. Secular variation of $\mathrm{Nd}$ and $\mathrm{Pb}$ isotopes in ferromanganese crusts from the Atlantic, Indian and Pacific Oceans. Earth Planet Sci Lett, 1998, 155: 15-28

18 Burton K W, Lee D C, Christensen J N, et al. Actual timing of neodymium isotopic variations recorded by FeMn crusts in the western North Atlantic. Earth Planet Sci Lett, 1999, 171: 149-156

19 van de Flierdt T, Frank M, Halliday A N, et al. Deep and bottom water export from the Southern Ocean to the Pacific over the past 38 million years. Paleoceanography, 2004, 19: PA1020

20 Sokolov S, Rintoul S. Circulation and water masses of the southwest Pacific: WOCE Section P11, Papua New Guinea to Tasmania. J Mar Res, 2000, 58: 223-268

21 Zhao G T, Peng J, Tian L Y, et al. Geochemistry of ferromanganese crusts and the tracing of paleocean environment (in Chinese). Period Ocean Uni China, 2004, 34: 886-892

22 Fu Y Z, Peng J T, Hu R Z, et al. A review on dating methods of ocean cobalt-rich ferromanganese crusts (in Chinese). Earth Environ, 2006, 34: 1-8

23 Banakar V K, Borole D V. Depth profiles of ${ }^{230} \mathrm{Th}_{\text {excess, }}$ transition metals and mineralogy of ferromanganese crusts of the Central Indian basin and implications for palaeoceanographic influence on crust genesis. Chem Geol: Isotope Geosci Section, 1991, 94: 33-44

24 Han X, Jin X, Yang S, et al. Rhythmic growth of Pacific ferromanganese nodules and their Milankovitch climatic origin. Earth Planet Sci Lett, 2003, 211: 143-157

25 Han X Q, Qiu Z Y, Ma W L, et al. High-resolution dating of Co-rich crusts: A comparative study using the methods of orbital pacing and ${ }^{230} \mathrm{Th}_{\mathrm{ex}}{ }^{232} \mathrm{Th}$ dating. Sci China Ser D-Earth Sci, 2009, 52: 484-488

26 Wu G H, A P I, Liu J H, et al. Biostratigraphic research on the seamount ferromanganese crusts of the mid-Pacific Ocean (in chinese). Acta Oceanol Sin, 2011, 33: 129-139

27 Cheng Z B, Shi X F, Su X, et al. Growth ages of ferromanganese crusts from the western and central pacific: Comparison between nannofossil analysis and ${ }^{10} \mathrm{Be}$ dating. Chin Sci Bull, 2006, 51: 3035-3040

28 Joshima M, Usui A. Magnetostratigraphy of hydrogenetic manganese crusts from Northwestern Pacific seamounts. Mar Geol, 1998, 146: 53-62

29 Oda H, Usui A, Miyagi I, et al. Ultrafine-scale magnetostratigraphy of marine ferromanganese crust. Geology, 2011, 39: 227-230

30 Westerhold T, Röhl U, Raffi I, et al. Astronomical calibration of the Paleocene time. Palaeogeogr Palaeoclimol Palaeoecol, 2008, 257: $377-403$

31 Ravizza G, Peucker-Ehrenbrink B. The marine ${ }^{187} \mathrm{Os} /{ }^{188} \mathrm{Os}$ record of the Eocene-Oligocene transition: The interplay of weathering and glaciation. Earth Planet Sci Lett, 2003, 210: 151-165

32 Klemm V, Levasseur S, Frank M, et al. Osmium isotope stratigraphy of a marine ferromanganese crust. Earth Planet Sci Lett, 2005, 238: 42-48

33 Fu Y Z, Peng J T, Qu W J, et al. Os isotopic compositions of a cobalt-rich ferromanganese crust profile in Central Pacifi. Chin Sci Bull, 2005, 50: 2106-2112

34 Klemm V, Frank M, Levasseur S, et al. Seawater osmium isotope evidence for a middle Miocene flood basalt event in ferromanganese crust records. Earth Planet Sci Lett, 2008, 273: 175-183

35 Li J S, Fang N Q, Qu W J, et al. Os isotope dating and growth hiatuses of Co-rich crust from central Pacific. Sci China Ser D-Earth Sci, 2008, 51: 1452-1459

36 Ding X, Gao L F, Fang N Q, et al. The relationship between the growth process of the ferromanganese crusts in the pacific seamount and Cenozoic ocean evolvement. Sci China Ser D-Earth Sci, 2009, 52 1091-1103

37 Segl M, Mangini A, Bonani G, et al. ${ }^{10} \mathrm{Be}$-dating of a manganese crust from Central North Pacific and implications for ocean palaeocirculation. Nature, 1984, 309: 540-543

38 Wang $\mathrm{X} \mathrm{H}$, Zhou L P, Wang Y M, et al. Paleoenvironmental implications of high-density records in Co-rich seamount crusts from the Pacific Ocean. Sci China Ser D-Earth Sci, 2008, 51: 1460-1469

39 Halbach P, Segl M, Puteanus D, et al. Co-fluxes and growth rates in ferromanganese deposits from central Pacific seamount areas. Nature, 1983, 304: 716-719

40 Manheim F T, Lane-Bostwick C M. Cobalt in ferromanganese crusts as a monitor of hydrothermal discharge on the Pacific sea floor. Nature, 1988, 335: 59-62

41 Puteanus D, Halbach P. Correlation of Co concentration and growth rate-A method for age determination of ferromanganese crusts. Chem Geol, 1988, 69: 73-85

42 Banakar V K, Pattan J N, Mudholkar A V. Palaeoceanographic conditions during the formation of a ferromanganese crust from the Afanasiy-Nikitin seamount, North Central Indian Ocean: Geochemical evidence. Mar Geol, 1997, 136: 299-315

43 Rajani R, Banakar V, Parthiban G, et al. Compositional variation and genesis of ferromanganese crusts of the Afanasiy-Nikitin Seamount, Equatorial Indian Ocean. J Earth Syst Sci, 2005, 114: 51-61

$44 \mathrm{Lu} \mathrm{Z} \mathrm{L,} \mathrm{Ling} \mathrm{H} \mathrm{F,} \mathrm{Zhou} \mathrm{F,} \mathrm{et} \mathrm{al.} \mathrm{Variation} \mathrm{of} \mathrm{the} \mathrm{Fe/Mn} \mathrm{ratio} \mathrm{of}$ ferromanganese crusts from the Central North Pacific: Implication for paleoclimate changes. Prog Nat Sci, 2005, 15: 530-537

45 Zhou F, Ling H F, Lu Z L, et al. Research of lead isotope of ferromanganese crusts from cental Pacific Ocean (in Chinese). Mar Geol Quat Geol, 2005, 25: 55-62

$46 \mathrm{Wu} \mathrm{G} \mathrm{H}$, Zhou H Y, Zhang H S, et al. New index of ferromanganese crusts reflecting oceanic environmental oxidation. Sci China Ser D-Earth Sci, 2007, 50: 371-384

47 Murray J W, Dillard J G. The oxidation of cobalt (II) adsorbed on manganese dioxide. Geochim Cosmochim Acta, 1979, 43: 781-787

48 Koschinsky A, Halbach P. Sequential leaching of marine ferromanganese precipitates: Genetic implications. Geochim Cosmochim Acta, 1995, 59: 5113-5132

49 Frank M, O'Nions R K, Hein J R, et al. 60 Myr records of major elements and $\mathrm{Pb}-\mathrm{Nd}$ isotopes from hydrogenous ferromanganese crusts: Reconstruction of seawater paleochemistry. Geochim Cosmochim Acta, 1999, 63: 1689-1708

50 Puteanus D. Geologie und Geochemie von Manganerzkrusten auf submarinen Gebirgen des Zentralpazifiks: Ein Beitrag zur Entwicklungsgeschichte mariner Erzkrusten. Arbeitsgruppe Meerestechnik und Marine Mineralrohstoffe, Technische Universität Clausthal, 1986, 9: 168

51 Wasserburg G J, Jacousen S B, DePaolo D J, et al. Precise determination of ratios, $\mathrm{Sm}$ and $\mathrm{Nd}$ isotopic abundances in standard solutions. Geochim Cosmochim Acta, 1981, 45: 2311-2323

52 Lugmair G W, Marti K. Lunar initial ${ }^{143} \mathrm{Nd} /{ }^{144} \mathrm{Nd}$ : Differential evolution of the lunar crust and mantle. Earth Planet Sci Lett, 1978, 39: $349-357$

53 Nielsen S G, Mar-Gerrison S, Gannoun A, et al. Thallium isotope evidence for a permanent increase in marine organic carbon export in the early Eocene. Earth Planet Sci Lett, 2009, 278: 297-307

54 Manheim F T. Marine cobalt resources. Science, 1986, 232: 600-608

55 Gourlan A T, Meynadier L, Allègre C J. Tectonically driven changes in the Indian Ocean circulation over the last 25 Ma: Neodymium isotope evidence. Earth Planet Sci Lett, 2008, 267: 353-364

56 Lacan F, Jeandel C. Tracing Papua New Guinea imprint on the central Equatorial Pacific Ocean using neodymium isotopic compositions and Rare Earth Element patterns. Earth Planet Sci Lett, 2001, 186: 497-512

57 Murphy D P, Thomas D J. The negligible role of intermediate water circulation in stadial-interstadial oxygenation variations along the southern California margin: Evidence from $\mathrm{Nd}$ isotopes. Quat Sci Rev, 2010, 29: 2442-2450 
58 Kaiho K, Saito S. Oceanic crust production and climate during the last 100 Myr. Terra Nova, 1994, 6: 376-384

59 Straub S M, Schmincke H U. Evaluating the tephra input into Pacific Ocean sediments: Distribution in space and time. Geol Rundsch, 1998, 87: 461-476

60 Hall R. Cenozoic geological and plate tectonic evolution of SE Asia and the SW Pacific: Computer-based reconstructions, model and animations. J Asian Earth Sci, 2002, 20: 353-431

61 Jicha B R, Scholl D W, Rea D K. Circum-Pacific arc flare-ups and global cooling near the Eocene-Oligocene boundary. Geology, 2009, 37: 303-306

62 Meynadier L, Allègre C, O’Nions R K. Plate tectonics, radiogenic isotopic tracers and paleoceanography: The case of the manganese crusts in the Pacific. Earth Planet Sci Lett, 2008, 272: 513-522

63 Kuhnt W, Holbourn A, Hall R, et al. Neogene history of the Indonesian throughflow. Geophys Monogr, 2004, 149: 299-320

64 Amakawa H, Alibo D S, Nozaki Y. Nd isotopic composition and REE pattern in the surface waters of the eastern Indian Ocean and its adjacent seas. Geochim Cosmochim Acta, 2000, 64: 1715-1727

65 Kennett J P, Keller G, Srinivasan M. Miocene planktonic foraminiferal biogeography and paleoceanographic development of the IndoPacific region. Geol Soc Am Mem, 1985, 163: 197-236

66 Cane M A, Molnar P. Closing of the Indonesian seaway as a precursor to east African aridification around 3-4 million years ago. Nature, 2001, 411: 157-162

67 Srinivasan M S, Sinha D K. Early Pliocene closing of the Indonesian Seaway: Evidence from north-east Indian Ocean and Tropical Pacific deep sea cores. J Asian Earth Sci, 1998, 16: 29-44

68 Jian Z, Yu Y, Li B, et al. Phased evolution of the south-north hydrographic gradient in the South China Sea since the middle Miocene. Palaeogeogr Palaeoclimatol Palaeoecol, 2006, 230: 251-263

69 Tsuchi R. Marine climatic responses to Neogene tectonics of the Pacific Ocean seaways. Tectonophysics, 1997, 281: 113-124

70 Gallagher S J, Wallace M W, Li C L, et al. Neogene history of the West Pacific Warm Pool, Kuroshio and Leeuwin currents. Paleoceanography, 2009, 24: PA1206

Open Access This article is distributed under the terms of the Creative Commons Attribution License which permits any use, distribution, and reproduction in any medium, provided the original author(s) and source are credited. 